$4-1-2014$

\title{
Understanding The Characteristics Of The Growth Of SMEs In B- To-B markets In Emerging Economies: An Organizational Ecology Approach
}

\author{
Patricia R. Todd \\ Western Kentucky University, patricia.todd@wku.edu \\ Rajshekhar G. Javalgi \\ Cleveland State University, r.javalgi@csuohio.edu \\ David Grossman \\ Goucher College, david.grossman@goucher.edu
}

Follow this and additional works at: https://engagedscholarship.csuohio.edu/bus_facpub

Part of the Business Administration, Management, and Operations Commons, Entrepreneurial and

Small Business Operations Commons, and the Marketing Commons

How does access to this work benefit you? Let us know!

Publisher's Statement

This is the Author Accepted Manuscript version of an article originally published in Journal of Business \& Industrial Marketing, 04-01-2014, http://dx.doi.org/10.1108/JBIM-08-2013-0189

\section{Original Published Citation}

Todd, P.R., Javalgi, R.G., \& Grossman, D. (2014). Understanding the characteristics of the growth of SMEs in B-to-B markets in emerging economies: An organizational eclology approach. Journal of Business \& Industrial Marketing, 29(4), 295-303. doi:10.1108/JBIM-08-2013-0189

This Article is brought to you for free and open access by the Monte Ahuja College of Business at EngagedScholarship@CSU. It has been accepted for inclusion in Business Faculty Publications by an authorized administrator of EngagedScholarship@CSU. For more information, please contact library.es@csuohio.edu. 


\title{
Understanding the characteristics of the growth of SMEs in B-to-B markets in emerging economies: an organizational ecology approach
}

Patricia R. Todd

Marketing and Sales, Western Kentucky University, Bowling Green, Kentucky, USA

Raj G. Favalgi

Nance College of Business Administration, Cleveland State University, Cleveland, Ohio, USA, and

David Grossman

International Business and Marketing, Goucher College, Baltimore, Maryland, USA

\begin{abstract}
Purpose - The aim of this paper is to focus on the determinants that impact the growth of SMEs in B-to-B markets in emerging economies. The objective is to apply the classic model of organizational ecology to examine the characteristics of growth patterns in the B-to-B environment for SMEs in emerging markets, specifically India and China. Application of the model can guide SMEs owners/managers in their effort to successfully expand internationally in turbulent markets characterized by competitive and technological intensity.

Design/methodology/approach - An overview of the basics of the organizational ecology model is presented, followed by the description of various economic drivers of B-to-B markets in India and China. The integration of the organizational ecology model and the strategic development of methods to deal with specific challenges of entering international markets are discussed. The paper concludes with managerial implications and suggestions for future research.

Findings - Businesses operating in emerging markets face many of the same roadblocks concerning efficiencies, increasing competition, and the need for capital, that are experienced by businesses throughout the world, however, they also face challenges unique to the developmental nature of the country environment. Ecological models can be used to understand the dynamics between resource utilization and growth.

Practical implications - The ecology-based view evaluates the utilization of resources with a focus on how changes in resource availability impact the international growth strategy of the B-to-B firm in India and China. These two economies represent a large business environment, generally underdeveloped with regards to taking advantage of potential resource availability.

Originality/value - While the significant economic contribution of SMEs is well understood, their business practices in emerging economies have not been extensively studied, especially in the B-to-B arena. The goal here is to stimulate the development of new insights for managing the complex relationships between the B-to-B SMEs, organizational ecology, and the international environment in emerging markets. This study extends the literature concerning factors that impact business success in important emerging markets such as India and China.
\end{abstract}

Keywords Ecology, Asia Pacific

Paper type Conceptual paper

\section{Introduction}

The integration of industries in the global economic environment, due to the rapid growth and development of communication and information technology, is changing the dynamics of international business. Successfully competing in a global business environment, one in which developing economies are playing a greater role, requires the understanding of international expansion patterns with the ultimate goal of positively effecting long term sustainability. Emerging markets offer long term growth opportunities that are difficult to find in mature and highly developed economies. Long term market growth potential in countries such as India and China is accelerated by the growth of a consumer base with increasing disposable income, large population of young and sophisticated consumers, and economic reforms (Todd and Javalgi, 2007).

Emerging markets represent a large opportunity for growth in business-to-business (B-to-B) firms due to derived demand originating from economic growth. Even though international 
trade is usually associated with larger, multinational organizations, small, innovative firms enter foreign markets, usually after operating successfully in their domestic environment. Increasing competitive intensity has created a need to identify and comprehend the value in knowing the impact of international factors so that strategies can be developed to overcome obstacles that small and medium sized enterprises (SMEs) in B-to-B markets encounter during international expansion (Etemad et al., 2001; Kuivalainen et al., 2004).

Over time, environmental pressures result in a firm's need to change or perish. Ecological models have been used to describe the manner in which firms adapt to dynamic and uncertain markets (Freeman and Boeker, 1984; Hannan and Freeman, 1977; Zammuto, 1988; Lomi et al., 2005). Hannan and Freeman (1977) developed the foundation of organizational ecology (OE) as they sought to explain the manner in which organizations come into existence and the way firms evolve into their various forms. Collaboration and efficient utilization of resources available to the firm is emphasized, especially during times in which business are faced with a turbulent or competitive environment. Environment pressures impact the success of an organization with regard to how the firm adapts its form, function, and overall strategy. Strategic choices made in reaction to resource availability as firms enter a market, along with the impact of the number and types of firms already doing business, influences the rate of market development (Lambkin and Day, 1989). Ecological models represent and predict the competitive dynamics within a business sector (Brittain and Freeman, 1980; Carroll and Delacroix, 1982; Hannan and Freeman, 1977). Organizational ecologists are interested in understanding the interrelationships among firms present in the organizational ecosystem, especially in regards to how they adapt in response to external factors such as increased competition and limitations on resource availability (Hannan and Freeman, 1989; Ozsomer and Cavusgil, 1999; Michael and Kim, 2005;).

The purpose of the study is to apply the classic model of organizational ecology and the characteristics of growth patterns in the B-to-B environment for SMEs in emerging markets, specifically India and China. Countries such as India and China contain the overwhelming majority of the world's population but a small percentage of the world GNP, resulting in a large potential for income growth (Levich, 2001). They have been characterized as being focused on rapid growth, with governmental pressure to increase economic activity (Ahlstrom and Bruton, 2006). Our goal is to stimulate the development of new insights for managing the complex relationships between organizational ecology and the expansion of B-to-B firms in the international environment. The underlying pattern found when comparing adaptation strategies found within nature is used to illustrate the way in which firms utilize resources in the uncertain and unpredictable environments characteristic of emerging markets. The outline of the paper is as follows. The basics of the organizational ecology model are presented, followed by the description of various economic drivers of B-to-B markets in India and China. The integration of the organizational ecology model and the strategic development of methods to deal with specific challenges of entering international markets are discussed. We conclude with managerial implications and suggestions for future research.
Over time, the creation and demise of organizations follow a cyclical pattern that can be explained by the availability of resources within the environment (Delacroix and Carroll, 1983). Rather than focusing on birth and mortality rates, our focus is on the impact of resource availability on the dynamics of the market.

\section{Theoretical foundations}

The theoretical building blocks providing the foundation for the conceptual focus presented are founded in historical research. The contribution of this paper is in linking the tenets of organizational ecology and international growth. The following sections define the background material essential to joining the two streams of research.

\section{Organizational ecology}

The environment in which firms of all types and structures (e.g. start-ups, born global) operate impacts the strategic decisions regarding operational activities. Over time, the creation and demise of organizations follow a cyclical pattern that can be explained by the availability of resources within the environment (Delacroix and Carroll, 1983). Rather than focusing on birth and mortality rates, our focus is on the impact of resource availability on the dynamics of the market. The environment or ecosystem's carrying capacity is the limit to growth of a business restrained the availability of resources necessary to maintain the population and is a key to the recognizing the impact of the relationship between growth and resource availability (Delacroix and Carroll, 1983). The B-to-B -ecosystem, with regards to this paper, is defined by the total business environment found in emerging markets in which the firm is operating. The population is defined as the number of firms within the emerging market and the unit of analysis is the entrepreneurial firm. The ability to support a population is dependent upon available resources and is referred to as the carrying capacity (Smith and Smith, 2001). Regional carrying capacities, in terms of local inputs and infrastructures, have been identified as limiting factors in industrial development (Gambarotto and Maggioni, 1998).

The support for our adaptation of organizational ecology to growth in emerging markets is derived from the equation that mathematically describes population growth and the impact of variations in the availability of resources, with a particular focus on population dynamics. The equation below describes the pattern of population growth within a defined environment. (Smith, 1974).

$$
\frac{\mathrm{dN}}{\mathrm{dt}}=\mathrm{rN}\left[\frac{\mathrm{K}-\mathrm{N}}{\mathrm{K}}\right]
$$

The rate of increase in growth is represented by $r$. Time is designated at $\mathrm{t}$. If $\mathrm{r}$ remains positive and there is no change in the environment, then exponential growth occurs. The above equation states that the rate of increase of a population is equal to the potential increase of the population times the proportion of the carrying capacity of the habitat that is still available (Smith, 1974). The limiting factor in this equation is the carrying capacity $(\mathrm{K})$. As the number of businesses operating within the environment increase (density) the competition for resources $(\mathrm{K})$ increases, resulting in a limitation on the growth of the population of firms. The growth of the population is slowed to a point where members 
of the population who cannot develop a survival strategy to adapt to the lack of resources will die unless the carrying capacity is raised. The equilibrium population size is represented by $\mathrm{N}$.

The application of the ecological theory of $\mathrm{r}$ and $\mathrm{K}$ can be made with a focus on the carrying capacity of the business environment. Advances in technology, as well as other structural factors, will impact the carrying capacity, or resource availability. The result significantly impacts the competitive environment. The ideal environment for an $r$ strategist is one that has large potential resource availability, with few competitors and minimal barriers to entry. Businesses that prove most successful in this environment are small and entrepreneurial (Ozsomer and Cavusgil, 1999). A business environment that is certain and predictable is best inhabited by a $\mathrm{K}$ strategist, focused on building internal efficiencies. These strategists are numerous developed countries where they enjoy relative stability in the external and internal environments they inhabit. Figure 1 illustrates the application of the population dynamics impacted by $\mathrm{r}$ and $\mathrm{K}$ strategies.

Figure 1 places emerging markets vs mature markets in their relative position as far population dynamics is concerned. While many countries, such as India and China are on the growth curve below the probable carrying capacity, it would appear that mature markets in the US and Europe are on the downward slope, headed toward a decline in growth until eventual equilibrium is reached. India and China represent a situation where many firms are experiencing a new business environment filled with uncertainty and risk. It is best described as an entrepreneurial climate. The discussion of key drivers fostering entrepreneurship in emerging markets follows.

\section{Drivers of growth in emerging markets}

A complete understanding of the structural characteristics of the particular emerging market is essential to the discussion of the accelerated internationalization of firms. International expansion and growth are facilitated by country specific, industry specific, firm specific, and market specific factors. Changes in these factors can raise or lower the carrying capacity, or resource availability. Table I provides a comparison between China, India, and the US. The US represents a stable business environment and on a large scale can be viewed as primarily $\mathrm{K}$ strategist in terms of business evolution. China and India would be considered $r$ strategists. In the following section, the country specific and firm specific factors that differentiate the $\mathrm{r}$ strategist from the $\mathrm{K}$ strategist are presented.

\section{Country specific factors}

Country specific factors, as shown in Table I, begin with the economic infrastructure. The GDP for China and India are obviously low but the population size and rate of growth are indicative of faster development typically found when an $r$ strategy is beginning. Both emerging markets are growing at a rate significantly faster than the US. The K strategist, such as the US, is focused on the service sector as it finds greater efficiencies in support the resource intensive industrial sector outside its borders. Examination of the international activities of India and China suggests that their potential for resource development makes them a target from partnering with the US. India's focus thrust is towards growing the B-to-B service sector of their economy. China, on the other hand, is focused more on the manufacturing, or industrial sector.

The technological infrastructure is also important to foster economic growth. Table I provides evidence concerning the

Figure 1 Growth dynamics in emerging markets

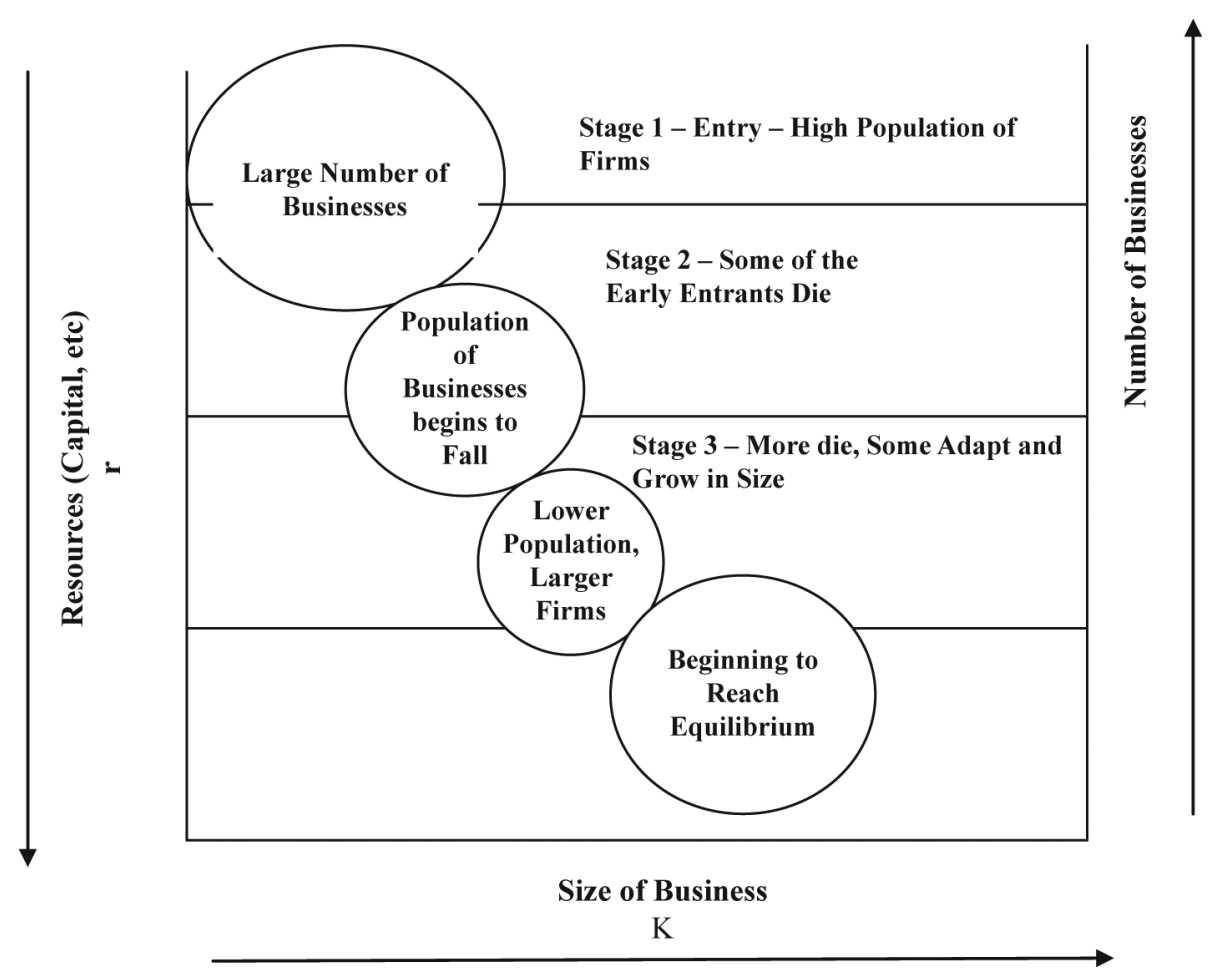


Table I Drivers of growth in India and China

\begin{tabular}{|c|c|c|c|}
\hline Indicators & China & India & USA \\
\hline Population (July 2007) est ${ }^{a}$ & $1,321,851,888$ & $1,129,866,154$ & $301,139,947$ \\
\hline \multicolumn{4}{|l|}{ Economic drivers: } \\
\hline GDP (Purchasing Power Parity) & $\$ 10.21$ trillion & $\$ 4.16$ trillion & $\$ 13.06$ trillion \\
\hline GDP (Official Exchange Rate) & $\$ 2.53$ trillion & $\$ 805.50$ billion & $\$ 13.16$ trillion \\
\hline GDP (Real Growth Rate) & $11.10 \%$ & $9.40 \%$ & $2.90 \%$ \\
\hline GDP (Per Capita) & $\$ 7,800$ & $\$ 3,800$ & $\$ 43,800$ \\
\hline \multirow[t]{3}{*}{ GDP- Composition by sector } & Agriculture: $11.7 \%$ & Agriculture: $17.5 \%$ & Agriculture: $0.9 \%$ \\
\hline & Services: $39.3 \%$ & Services: $54.6 \%$ & Services: $78.2 \%$ \\
\hline & Other industry: $48.9 \%$ & Other industry: $27.9 \%$ & Other industry: $20.9 \%$ \\
\hline Unemployment rate ${ }^{a}$ & $\begin{array}{l}4.2 \% \text { official registered unemployment in urban areas in } 2005 \text {; } \\
\text { substantial unemployment and underemployment in rural } \\
\text { areas (2005) }\end{array}$ & $7.8 \%$ (2006 est.) & $4.8 \%$ (2006 est.) \\
\hline Inflation rate & $1.70 \%$ & $6.20 \%$ & $3.20 \%$ \\
\hline Investment (gross fixed) & $40.9 \%$ of GDP & $29.5 \%$ of GDP & $16.4 \%$ of GDP \\
\hline Public debt & $22.1 \%$ of GDP & $60 \%$ of GDP & $\begin{array}{l}64.7 \% \text { of GDP }(2005 \\
\text { est.) }\end{array}$ \\
\hline Industrial prod. growth rate & $22.90 \%$ & $7.50 \%$ & $4.20 \%$ \\
\hline Exports, $2006^{\mathrm{a}}$ & $\$ 969.7$ billion f.o.b. & $\$ 123.2$ billion f.o.b. & $\$ 1.023$ trillion f.o.b. \\
\hline \multirow[t]{5}{*}{ Export partners, $2006^{a}$} & US $21 \%$ & US $17.2 \%$ & Canada $22.2 \%$ \\
\hline & Hong Kong 16\% & UAE $8.4 \%$ & Mexico $12.9 \%$ \\
\hline & Japan $9.5 \%$ & China $7.8 \%$ & Japan $5.8 \%$ \\
\hline & South Korea 4.6\% & UK $4.4 \%$ & China 5.3\% \\
\hline & Germany $4.2 \%$ & & UK $4.4 \%$ \\
\hline Imports, $2006^{a}$ & $\$ 751.9$ billion f.o.b. & $\$ 184.4$ billion f.o.b. & $\$ 1.861$ trillion f.o.b. \\
\hline \multirow[t]{5}{*}{ Import partners, $2006^{a}$} & Japan $14.6 \%$ & China $8.5 \%$ & Canada $16 \%$ \\
\hline & South Korea $11.3 \%$ & US $5.9 \%$ & China $15.9 \%$ \\
\hline & Taiwan $10.9 \%$ & Germany $4.5 \%$ & Mexico $10.4 \%$ \\
\hline & US $7.5 \%$ & Singapore $4.5 \%$ & Japan $7.9 \%$ \\
\hline & Germany $4.8 \%$ & & Germany $4.8 \%$ \\
\hline \multirow[t]{2}{*}{ FDI (in millions) $2006^{b}$} & Inward - \$69,468 & Inward - \$16,881 & Inward - \$175,394 \\
\hline & Outward - \$16,130 & Outward - \$9,676 & Outward - \$216,614 \\
\hline \multirow[t]{3}{*}{ FDI Stocks (in millions), $2006^{\mathrm{b}}$} & Inward - \$292,559 & Inward - \$50,680 & Inward - \$1,789,087 \\
\hline & as a $\%$ of GDP- Inward - $11.1 \%$ & $\begin{array}{l}\text { as a } \% \text { of GDP - } \\
\text { Inward }-5.7 \%\end{array}$ & $\begin{array}{l}\text { as a } \% \text { of GDP - } \\
\text { Inward }-13.5 \%\end{array}$ \\
\hline & as a $\%$ of GDP - outward - $2.8 \%$ & $\begin{array}{l}\text { as a } \% \text { of GDP - } \\
\text { outward }-1.5 \%\end{array}$ & $\begin{array}{l}\text { as a } \% \text { of GDP - } \\
\text { outward }-18.0 \%\end{array}$ \\
\hline $\begin{array}{l}\text { Cross border merger and } \\
\text { acquisition: sales }{ }^{\mathrm{b}}\end{array}$ & $\$ 6,724$ (in millions) & $\$ 6,716$ (in millions) & $\$ 172,174$ (in millions) \\
\hline $\begin{array}{l}\text { Foreign Direct Investment, } \\
\text { Inflows }(2004)^{d}\end{array}$ & $\$ 60,630$ (in millions) & $\$ 5,335$ (in millions) & $\$ 95,859$ (in millions) \\
\hline \multicolumn{4}{|l|}{ Technology drivers } \\
\hline $\begin{array}{l}\text { Telephones - mobile in use, } \\
2006^{a}\end{array}$ & 461.1 million & 166.1 million & 233 million \\
\hline Internet hosts, $2007^{\mathrm{a}}$ & 10.637 million & 2.306 million & 3.95 million \\
\hline Internet users ${ }^{a}$ & 137 million (2006) & 60 million (2005) & 208 million \\
\hline $\begin{array}{l}\text { US trade balance in advanced } \\
\text { technology products }{ }^{c}\end{array}$ & $-\$ 49,327.0$ (in millions) & $\$ 2,557.9$ (in millions) & - \\
\hline $\begin{array}{l}\text { US exports of advanced } \\
\text { technology products, } 2006^{c}\end{array}$ & $\$ 24,166.6$ (in millions) & $\$ 3,251.1$ (in millions) & - \\
\hline $\begin{array}{l}\text { US imports of advanced } \\
\text { technology products, } 2006^{c}\end{array}$ & $\$ 73,493.6$ (in millions) & $\$ 693.2$ (in millions) & - \\
\hline
\end{tabular}

Notes: ${ }^{a}$ CIA World Fact book, available at: www.cia.gov/library/publications/the-world-factbook/; ${ }^{b}$ UNCTAD, World Investment Report 2007, available at: www.

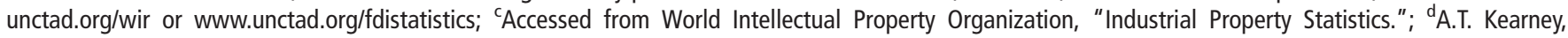
available at: www.atkearney.com/main.taf? $\mathrm{p}=5,4,1,127,1$ \#data

Source: This information was gathered from the US Census Bureau, Foreign Trade Division, Special Tabulation (March 2007). 
level of focus on innovation and proactiveness. The trade in advanced technology, services, and information technology support clearly shows that India has been establishing itself as a global leader in the IT and related industries. Emerging markets differ in the amount progress in developing the infrastructure necessary to foster growth. For example, India, even though a major exporter of information technology support and services, has the lowest growth rates of e-business within the Asian region surveyed. India is among the lowest in terms of the infrastructure needed to support e-commerce, and the highest in terms of cost to access. They were the only country with single digit growth rates, primarily due to their slow development of the telecommunications sector. In many developing countries, there is very low PC penetration and tele-density is very low in comparison to the rest of the world. In India, as shown in Table I, approximately 10 percent of the population had telephones, whereas in China, approximately 40 percent have telephones. Even though, in 2005, ecommerce in India represented a $\$ 41.5$ billion industry, the growth of Internet usage remains slow (Rastogi, 2005). The Indian government has always supported the growth of SMEs by developing policies that provided protection to small businesses, creating barriers to entry for foreign competition (Sheth, 2004). In 1997, however, the focus of the government moved from protectionism to one of promoting stability and growth, essentially removing the domestic firm's competitive advantage (Manimala et al., 2001). In contrast, the Chinese government has been implementing market reforms and the leaders have officially sanctioned profit-seeking and growth, adapting to the changing global environment (Duckett, 2001).

The government representing an emerging market should also play an active role to insure that smaller companies can develop a competitive advantage in their sector. The lack of formal institutions necessary for rapid growth in emerging markets has resulted in the creation of informal networks, acting as conduits for building relationships with venture capitalists, customers, suppliers and government (Ahlstrom and Bruton, 2006). Research and development and a focus on higher education, especially in the engineering discipline, is of prime importance as an emerging market seeks to build the availability of skilled human capital (Kapur, 2002; O'Malley and O'Gorman, 2001).

In emerging markets, socio-cultural factors have been recognized as important environmental factors explaining systematic differences in adopting products and services. Language, education, and technical infrastructure are the three major reasons cited for a country or region lagging behind in the growth (Sprano and Zakak, 2000). For example, due to the British influence on India's history, the educated level of the population, generally at the upper class level, is comfortable using the English language (Siegel, 2006).

The regulatory and commerce infrastructures play a significant role in the economic growth of an emerging market (Javalgi and Ramsey, 2001). Once the country decides to support international trade, regulatory procedures, and legal frameworks have to be changed. Intellectual property, particularly copyright and piracy rates are some of the issues that must be resolved before international trade will reach its potential.

\section{Firm specific factors}

Country specific factors enable firm specific capabilities. As country specific factors develop, firms can leverage their characteristic operating style to take advantage of their early entry into the international market. Ahlstrom et al. (2006) identify six commonalities that are typically found in Chinese firms doing business in East Asia. They include; family control, simple organizational structures, centralized decision making, internal financing, minimal advertising, lack of spending on research and development. Additional firm specific assets such as complex regulatory, human, technological, physical, and capital become critically important as the firm grows in its size, scale and scope. These become more important as the $\mathrm{K}$ strategy emerges. Local availability of resources, infrastructure, and the firm's ability to access support services are important factors that determine the size of the carrying capacity of the international ecosystem (Gambarotto and Maggioni, 1998).

In the following section, the connection between growth and organizational ecology characteristics as they pertain to $r$ and $\mathrm{K}$ strategy, with a focus on the concepts related to niche width and organizational form will be discussed.

\section{Niche width}

In a natural ecosystem, the available supporting resources and the competitive intensity residing within the boundaries in which the organism is living defines its niche (Lambkin and Day, 1989). In organizational ecology, the niche consists of all of the support services, financial capital, human capital, customer base and competitors that act as resources to insure the survival of the firm (Michael and Kim, 2005). While several characteristics can be used describe the unique aspect of organizations occupying separate niches, one particular characteristic commonly known as 'niche width' has received much attention in the organization ecology literature (Freeman et al., 1983; Lambkin and Day, 1989). Niche width defines the range of resource availability and the breadth of markets in which the firm operates (Sorenson et al., 2006). The ability to survive and adapt to the changing environment requires investing organizational resources (e.g. capital and human) and such decisions, to a large extent, are influenced by the selection of $\mathrm{r}$ and $\mathrm{K}$ in the ecosystem.

In the US, the available niche width for most industries is vast due to the availability of advanced infrastructure and technology and its relatively open market economy. China and India, on the other hand, due to their history of closed markets and lack of infrastructure, are presenting a narrow niche width. Organisms with an r-strategy are expected to grow at a faster rate when in an environment with excess capacity, while organisms with a K strategy have an advantage when the resources become limited (Blagodatskaya et al., 2004).

India and China represent business environments with potential excess in carrying capacity $(\mathrm{K})$. As firms innovate and take the risk of developing, the necessary resources in these countries begin to establish, their growth in numbers will be increased. This growth depends on leveraging capabilities that are related to $r$ strategy. Organizations following an $r$ strategy will move into a niche in order to take advantage of abundant resources while $\mathrm{K}$ strategists focus on survival within densely populated environments (Brittain and Freeman, 1980). Firms that follow the $r$ strategy are those 
that quickly move in to take advantage of being first to market, while $\mathrm{K}$ strategists follow and gain competitive advantage through their efficiencies (Brittain and Freeman, 1980).

No organism is completely $\mathrm{r}$ selected or $\mathrm{K}$ selected but rather all have reached a compromise between the two extremes. The variable referred to as niche width has been used to represent the strategic progression from generalism to specialism (Lambkin and Day, 1989). The $r$ strategists evolve as the uncertainty is reduced within the business environment. They become larger scale generalist organizations that can survive by utilizing a wider range of environmental resources (Lambkin and Day, 1989). Generalists tend to have a broader scope, aim its products or services at a broad range of consumer tastes in the market, and may be better at adapting to environmental changes (Sorenson et al., 2006; Witteloostuijn and Boone, 2006). The key is with the development of the necessary reforms and infrastructure, the niche width will expand. The entrepreneurial $\mathrm{r}$ strategists, who were first to market, will then be able to widen their business scope and move toward evolving into $\mathrm{K}$ strategists.

K strategists, such as found in the US market, on the other hand, become generalists with the resources to enter the market with an established brand name and high quality products. The $\mathrm{K}$ specialists are smaller scale firms that tend to be late entrants to the market (Lambkin and Day, 1989). The types of competitive strategies typically used by $\mathrm{K}$ specialists are those characterized by lowest cost production, vertical integration, and stand-alone divestment (Lambkin and Day, 1989).

\section{Legitimacy of organizational forms}

Legitimacy refers to how well the organizational form is accepted by society and whether the firm's product offerings and operating procedures fit the expectations for similar firms already in the business environment (Rindova et al., 2007). As organizations change over time, they are characterized by different forms and gain membership into business communities possessing specific types of collective organizational identities (Hannan, 2005). The importance of organizational form, particularly in developing strategy for survival, has been emphasized by several researchers (Hannan and Freeman, 1989; Michael, 1994; Michael and Kim, 2005). Organizational form, with reference to $r$ and $K$ selection, can be viewed in terms of firm size. Organizational and economic theorists propose that larger organizations have a competitive advantage due to their ability to reduce their dependence on the environment and other organizations (Nunez-Nichol and Moyano-Fuentes, 2006). Larger organizations have advantages based on economies of scale, availability of capital, established brand equity, and power within the market (Pfeffer and Salancik, 1978; Woo and Cooper, 1991; Michael and Kim, 2005). The results are superior market power along with greater access. Smaller organizations in India and China have the advantage of government support, familial networks, and the flexibility to allow them to establish a foothold in the market. In the software industry, it is reported that the smaller Indian firms are younger, rely on entrepreneurial vision, show the greatest exporting activities and experience the fastest growth (Contractor and Kundu, 2004).

\section{Liability of newness}

Many smaller firms, especially in India, are represented by start-ups that born global especially since economic reforms in both countries (Oviatt and McDougall, 1994; Contractor and Kundu, 2004). Born global firms are defined as small, entrepreneurial firms that are focused on international activities from inception (Freeman and Cavusgil, 2007).

Stinchcombe (1965) when developing his theory concerning the 'liability of newness,' hypothesized that younger organizations are more likely to fail due to high start-up costs and the lack of established relationships with support services. Organizational forms within emerging markets are impacted heavily by the liability of newness, especially for smaller entrepreneurial startups. Newly formed companies, within the domestic environment, can suffer from a lack of resources, especially in terms of complementary resources (Cuervo-Cazurra et al., 2007). New firms, especially those entering emerging markets, are faced with the challenge of reducing uncertainty for stakeholders by demonstrating their ability to meet the guidelines and operational tactics set by firms already operating in the industry (Rindova et al., 2007). In this way, they become members of the organizational collective and are supported by the ability to leverage the positive characteristics of the other members within the industry.

Private businesses operating in China are limited by lack of long term financial resources, lack of managerial, marketing, and technical skills (Poutziouris et al., 2002). Another limitation is a general distrust entrepreneurs feel towards the Chinese government and its proclaimed changes in policy (Poutziouris et al., 2002). The members of the organizational collective for these firms include complex networks formed by familial ties and the relationships that have developed with other South East Asian firms (Poutziouris et al., 2002).

The growth of firms, as it relates to $\mathrm{r}$ and $\mathrm{K}$ selection can be described by three stages of development (Javalgi et al., 2004). The following section evaluates the process of growth as it relates to $\mathrm{r}$ and $\mathrm{K}$ selection strategies and the establishment of competitive advantage.

\section{Growth and survival}

Firms expanding into international markets are faced with a great deal of uncertainty and risk. Figure 2 provides an illustration of the application of $r$ and $K$ strategy to international expansion in an emerging market.

Initially, in stage 1, resources become available and firms, as $r$ strategists may begin to enter the market, due to their entrepreneurial characteristics. For example, the support services that have developed in India, as a result of the success of information technology development, represent the early entrants into the IT sector. Early entrants in the Chinese market are focused on manufacturing support (Contractor and Kundu, 2004). Since the competitive intensity is low, many smaller companies will enter the marketplace. If the carrying capacity will sustain the market, soon there will be many companies entering into the picture. As resources become scarce, competition increases, the environment begins to favor firms that can adapt. Strategically important factors that emerge at this time consist of social and governmental infrastructures, communication technology, commercial infrastructure and economic stability (Javalgi and Ramsey, 2001). 
Figure 2 Estimates of the relative position of emerging vs mature markets based on resource availability as it relates to $\mathrm{r}$ and $\mathrm{K}$ selection

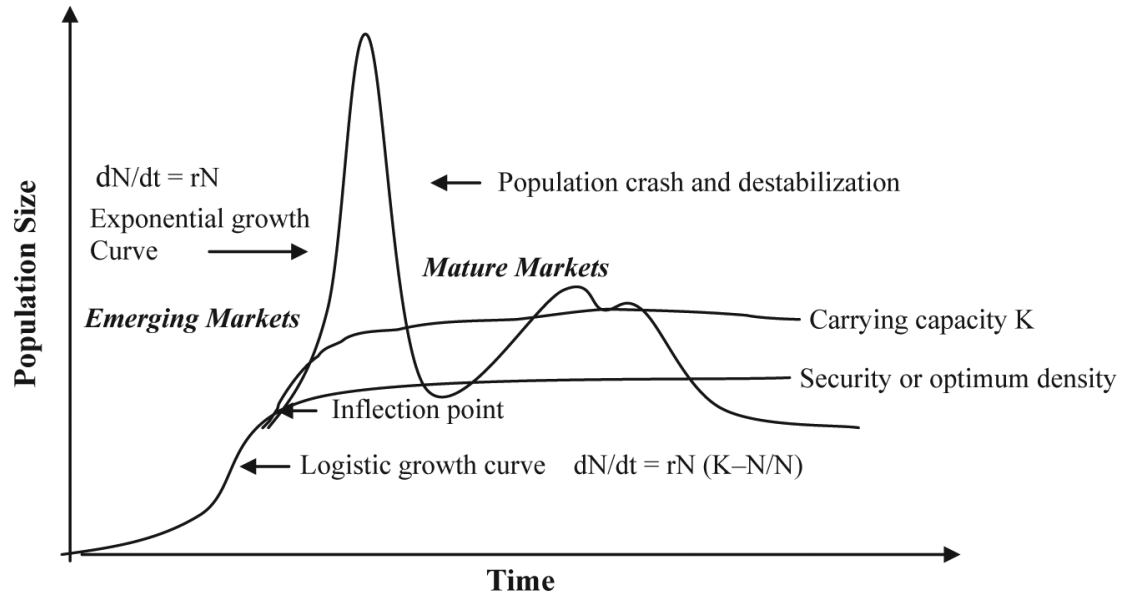

During stage two, as resources become limited, some of the smaller, less fit firms will fail. Eventually, the $r$ strategists begin to adapt as the uncertainty and turbulence is reduced. The characteristics of the $\mathrm{K}$ strategist become more visible. They may transform into larger scale organizations that can survive by utilizing a wider range of environmental resources, networks or become more specialized (Lambkin and Day, 1989).

Stage three is characterized by market saturation and density dependency becomes an issue as organizations begin to compete for limited resources. Competitive intensity is very high and firms either begin to adapt or are replaced. Competitive intensity is very high, due to the survival of the firms that are more flexible and efficient. Firms must find a differentiated position or a unique efficiency to sustain their business position. The final stage is characterized by balance in the marketplace. Remaining firms are focused on internal factors, specifically improving efficient utilization of existing resources. Firms that are unable to take advantage of the evolution of resource availability will not survive.

\section{Implications}

Business-to-business firms in emerging markets, as represented by India and China, are seeking to develop competitive advantage based on existing capabilities, including technological, social, and natural resources. The ecology-based view evaluates the utilization of resources with a focus on how changes in resource availability impact the international growth strategy of the B-to-B firm in India and China. These two economies represent a large business environment, generally underdeveloped with regards to taking advantage of potential resource availability. Our goal is to stimulate the development of new insights for managing the complex relationships between the B-to-B SMEs, organizational ecology, and the international environment.

The business environment that promotes the growth and survival of a firm that is an $r$ strategist is one that is large with an abundance of resources, and few barriers to entry. The business environment in India and China has the potential for development of abundant resources. Reforms in their economic environment and governmental support are drivers of domestic business growth. At this time, strategies related to organizational ecology can be used in emerging markets to establish a competitive advantage. The availability of resources is not an issue at this time. For example, a firm following an $\mathrm{r}$ strategy could be small and entrepreneurial. Productivity is their focus. $\mathrm{K}$ strategists, on the other hand, survive in a climate that is constant and predictable. The market is mature and saturated resulting in high competitive intensity. The organization focuses on internal growth and improving efficiency as resource availability becomes an issue.

\section{Conclusions and future research}

Ecological models have long been used by researchers in many fields to explain the dynamics of living systems. Organizational strategy scholars have further developed these concepts resulting in the evolution of a stream of research that applies ecological models to the business environment. The recognition of the growing economic importance and the future growth potential in emerging markets, especially India and China, has led to growing interest in strategy development. Businesses operating in emerging markets face many of the same roadblocks concerning efficiencies, increasing competition, and the need for capital, that are experienced by businesses throughout the world, however, they also face challenges unique to the developmental nature of the country environment. Firms desiring to expand in emerging markets face considerable challenges and the dynamic environmental variables, such as changes in infrastructure, technology, and governmental policies require careful attention both entrepreneurs and policy makers. Ecological models can be used to understand the dynamics between resource utilization and growth. In order to successfully survive in emerging markets, upper level management or owners, need to develop strategies that will promote the behaviors that aid in successful expansion.

The environmental forces in which a business must operate are constantly changing forcing firms to adapt their strategies to entering and sustaining growth in new markets. Empirical studies are needed to ascertain the degree to which firms in emerging markets follow the ecological model; especially, identifying factors that both derive and inhibit their success. A second research avenue to consider should focus on organizational characteristics (e.g. size of company, 
resources, and management structure) that change over time and allow a company to survive. Methodologically, future research should acknowledge differences among the growth rate of various business sectors in emerging markets and the relative differences in importance among environmental factors impacting the carrying capacity.

\section{References}

Ahlstrom, D. and Bruton, G. (2006), "Venture capital in emerging economies: networks and institutional change", Entrepreneurship Theory and Practice, March, pp. 299-320.

Blagodatskaya, E.V., Ermolaev, A.M. and Myakshina, T.N. (2004), "Ecological strategies of soil microbial communities under plants of meadow ecosystems", Biology Bulletin, Vol. 6, pp. 620-627.

Brittain, J. and Freeman, J. (1980), "Organizational proliferation and density dependent selection", in Kimberly, J.R. and Miles, R.H. (Eds), The Organization Life Cycle, Jossey-Bass, San Fransisco, CA, pp. 291-338.

Carroll, G.R. and Delacroix, J. (1982), "Organizational mortality in the newspaper industries of Argentina and Ireland", Administrative Science Quarterly, Vol. 27, pp. 169-198.

Contractor, F.J. and Kundu, S. (2004), "The role of exportdriven entrepreneurship in economic development: a comparison of software exports from India, China, and Taiwan", Technological Forecasting and Social Change, Vol. 71, pp. 799-822.

Cuervo-Cazurra, A., Maloney, M. and Manrajhan, S. (2007), "Causes of the difficulties in internationalization", fournal of International Business Studies., Vol. 38 No. 5, pp. 709-725.

Delacroix, J. and Carroll, G.R. (1983), "Organizational foundings: an ecological study of the newspaper industries of Argentina and Ireland", Administrative Science Quarterly, Vol. 28, pp. 274-291.

Duckett, J. (2001), "Bureaucrats in business, Chinese style: the lessons of market reform and state entrepreneurialism in the People's Republic of China", World Development, Vol. 29 No. 1, pp. 23-37.

Etemad, H., Wright, R.W. and Dana, L.P. (2001), "Symbiotic international business networks: collaboration between small and large firms", Thunderbird International Review, Vol. 43, pp. 211-219.

Freeman, J. and Boeker, W. (1984), "The ecological analysis of business strategy", California Management Review, Vol. 26 No. 3, pp. 73-86.

Freeman, J., Carroll, G.R. and Hannan, M.T. (1983), "The liability of newness: age dependence in organizational death rates", American Sociological Review, Vol. 48, pp. 692-710.

Freeman, S. and Cavusgil, S.T. (2007), "Toward a typology of commitment states among managers of Born-Global firms: a study of accelerated internationalization", fournal of International Marketing, Vol. 15 No. 4, pp. 1-40.

Gambarotto, F. and Maggioni, M. (1998), "Regional development strategies in changing environments: an ecological approach", Regional Studies, Vol. 32 No. 1, pp. 49-62.

Hannan, M.T. (2005), "Ecologies of organization: diversity identity", Fournal of Economic Perspective, Vol. 19, pp. 51-70.

Hannan, M.T. and Freeman, J. (1977), "Population ecology of organizations", American fournal of Sociology, Vol. 82 No. 5, pp. 929-964.
Hannan, M.T. and Freeman, J. (1989), Organizational Ecology, Harvard University Press, Cambridge, MA.

Javalgi, R., Todd, P.R. and Scherer, R. (2004), "Factors influencing the internationalization of e-commerce: towards a systems dynamics approach", in Samaii, M. and Karush, G. (Eds), International Business and Information Technology, Routledge, New York, NY.

Javalgi, R.G. and Ramsey, R. (2001), "Strategic issues of e-commerce as an alternative global distribution system", International Marketing Review, Vol. 18, pp. 376-391.

Kapur, D. (2002), "The causes and consequences of India's IT boom", India Review, Vol. 1 No. 2, pp. 91-110.

Kuivalainen, O., Sundqvist, S., Puumalainen, K. and Cadogan, J.W. (2004), "The effect of environmental turbulence and leader characteristics on international performance: are knowledge based firms different?", Canadian Fournal of Administrative Sciences, Vol. 21 No. 1, pp. 35-50.

Lambkin, M. and Day, G.S. (1989), "Evolutionary processes in competitive markets: beyond the product life cycle", Fournal of Marketing, Vol. 53 No. 3, pp. 4-20.

Levich, R.M. (2001), "The importance of emerging capital markets", Brookings-Wharton Papers on Financial Services, pp. 1-45.

Lomi, A., Larson, E.R. and Freeman, J.H. (2005), "Things change: dynamic resource constraints and systemdependent selection in the evolution of organizational populations", Management Science, Vol. 51 No. 6, pp. 882-903.

Manimala, M.J., Gopal, M.V., Prakhya, S. and Shields, J. (2001), GEM India Report 2001, Indian Institute of Management, Bangalore, India.

Michael, S.C. (1994), "Competition between organizational forms: mail order versus retail stores, 1910-1940", fournal of Economic Behavior and Organization, Vol. 23, pp. 269-286.

Michael, S.C. and Kim, S. (2005), "The organizational ecology of retailing: a historical perspective", fournal of Retailing, Vol. 81 No. 2, pp. 113-123.

Nuenz-Nickol, M. and Moyano-Fuentes, J. (2006), "New size measurements in population ecology", Small Business Economics, Vol. 26, pp. 61-81.

O'Malley, E.O. and O'Gorman, C. (2001), "Competitive advantage in the Irish indigenous software industry and the role of inward foreign direct investment", European Planning Studies, Vol. 9 No. 3, pp. 303-321.

Oviatt, B.M. and McDougall, P.P. (1994), "Toward a theory of international new ventures", fournal of International Business Studies, Vol. 25 No. 2, pp. 45-64.

Ozsomer, A. and Cavusgil, S.T. (1999), "A dynamic analysis of market entry rates in a global industry: a community ecology perspective", European fournal of Marketing, Vol. 33 Nos 11/12, pp. 1038-1063.

Pfeffer, J. and Salancik, G.R. (1978), The External Control of Organizations: A Resource Dependence Perspective, Harper \& Row, New York, NY.

Poutziouris, P., Wang, Y. and Chan, S. (2002), "Chinese entrepreneurship: the development of small family firms in China", Fournal of Small Business and Enterprise Development, Vol. 9 No. 4, pp. 383-399.

Rastogi, R. (2005), "Initiatives for e-commerce capacitybuilding of SMEs in India", Country Presentations, pp. 147-157. 
Rindova, V.P., Petkova, A.P. and Kotha, S. (2007), "Standing out: how new firms in emerging markets build reputation", Strategic Organization, Vol. 5, pp. 31-70.

Sheth, J. (2004), "Making India globally competitive", Vikalpa, Vol. 29 No. 4, pp. 1-9.

Siegel, J. (2006), "India vs. China: who has the edge", Yahoo Finance, available at: http://finance.yahoo.com/columnist/ article/futureinvest/2369? $\mathrm{p}=1$ (accessed 2 January 2006).

Smith, R.L. (1974), Ecology and Field Biology, 2nd ed., Harper \& Row, New York, NY.

Smith, R.L. and Smith, T.M. (2001), Ecology and Field Biology, 6th ed., Cummings, San Francisco, CA.

Sorenson, O., McEvily, S., Ren, C.R. and Roy, R. (2006), "Niche width revisited: organizational scope, behavior and performance", Strategic Management fournal, Vol. 27, pp. 915-936.

Sprano, E. and Zakak, A. (2000), "E-commerce capable: competitive advantage for countries in the new world e-conomy", Competitiveness Review, Vol. 10 No. 2, pp. 114-131.

Stinchcombe, A.L. (1965), "Social structures and organizations", in March, J.G. (Ed.), Handbook of Organizations, Rand McNally, Chicago, IL, pp. 142-193.

Todd, P.R. and Javalgi, R.G. (2007), "Internationalization of SMEs in India: fostering entrepreneurship by leveraging information technology", International fournal of Emerging Markets, Vol. 2 No. 2, pp. 166-180.

Witteloostuijn, A.V. and Boone, C. (2006), "A resourcebased theory of market structure and organizational form", Academy of Management Review, Vol. 31 No. 2, pp. 409-426.

Woo, C. and Cooper, A. (1991), "Strategies of effective low share businesses", Strategic Management fournal, Vol. 2, pp. 301-318.
Zammuto, R. (1988), "Organizational adaptation: some implications of organizational ecology for strategic change", fournal of Management Studies, Vol. 25 No. 2, pp. 105-120.

\section{Further Reading}

Ahlstrom, D., Young, M.N., Chan, E.S. and Bruton, G.D. (2004), "Facing constraints to growth? Overseas Chinese entrepreneurs and traditional business practices in East Asia", Asia Pacific fournal of Management, Vol. 21, pp. 263-285.

Delacroix, J. and Carroll, G.R. (2006), "Doing business in India”, Global Technology Forum, available at: http://global techforum.eiu.com/index.asp?layout=newdebiandcountry $\mathrm{id}=\mathrm{INandcountry}=$ Indi. . . (accessed September 2006).

Kula, V. and Tatoglu, E. (2003), "An exploratory study of Internet adoption by SMEs in an emerging market economy", European Business Review, Vol. 15 No. 5, pp. 324-333.

McGrath, R.G., MacMillan, I.C. and Venkataraman, S. (1995), "Global dimensions of new competencies", in Birley, S. and MacMillan, I.C. (Eds), International Entrepreneurship, Routledge, New York, NY.

Porter, M. (1990), The Competitive Advantage of Nations, Collier-MacMillan, London.

Romanelli, E. (1987), "New venture strategies in the microcomputer industry", California Management Review, Vol. 30, pp. 160-175.

\section{Corresponding author}

Raj G. Javalgi can be contacted at: r.javalgi@csuohio.edu 